\title{
THE NEW EUROPEAN DIRECTIVE 2013/34 / EU ON THE FINANCIAL STATEMENTS. EVIDENCE ABOUT ITS INTRODUCTION IN THE ITALIAN ACCOUNTING SYSTEM
}

\author{
ROBERTA PROVASI \\ University of Milan-Bicocca \\ Italy \\ roberta.provasi@unimib.it
}

\begin{abstract}
With the Directive no. 2013/34 / EU dated 26 June 2013 the Parliament and the European Council have decreed a new era for the financial statements of companies in the European Union member countries. The introduction of this new directive aims to improve the coverage information of the accounting document and to begin a process of simplification of administrative burdens and standards for the preparation and publication of the financial statements. In Italy the directive must be transposed by 20 July 2015 for which the associations of accountants are evaluating the specific contents of the new rules to make application for Italian companies. Some of the new rules and above all part of the new structures of the schemes of the financial statements are quite different from the approaches currently in use for which discussions are taking place very heated.
\end{abstract}

\section{Keywords: EUROPEAN DIRECTIVE 2013/34/EU, FINANCIAL STATEMENTS, NEW ITALIAN ACCOUNTING SYSTEM}

\section{INTRODUCTION}

The purpose of the new European Directive 2013/34/EU of 06.26.2013 is to renew the legislation on the financial statements and the consolidated financial statements too by repealing the previous European directives namely the No. 660 of 1978 known as IV Directive and No. 349 of 1983, known as the EEC Directive VII. The objectives of this update are attributable to.

1) To encourage the process of European accounting harmonization so that the financial statements of the companies are drawn up following the same rules of form and content and therefore perfectly comparable;

2) To find an appropriate balance between the stakeholders and the need for firms to not be overly burdened by obligations of accounting information.

In fact, the new Directive takes account of the provisions contained in the European Commission adopted in October 2010 titled "Smart Regulation in the European Union" aims to develop high standards of quality while ensuring a balance between the information requested and the burden of obligations imposed on businesses. The economic reality of the European Union is in fact made up of mostly small and medium-sized enterprises to which the Directive is addressed through simplifications and exemptions.

The reason is to avoid excessive costs for small businesses to comply with the disclosure requirements imposed. The Directive also refers to the European Commission communication entitled "Think Small First - A new basic framework for the Small Business (A Small Business Act for Europe) adopted in June 2008 and revised in February 2011, which recognizes the central role played by SMEs in the EU economy and aims to improve the overall approach to entrepreneurship. Another reference is to the Commission communication entitled "The High Single Market Act" enacted in April 2011, which aims to simplify the IV and VII of the Directive in order to improve the business climate and promote the internationalization especially for small and medium-sized businesses. 
Finally, December 18, 2008 the European Parliament adopted a resolution stating that the Accounting Directives are often very burdensome for small and medium-sized enterprises asking precisely to the Commission for a review of those directives. The objective of this research is to analyze the main changes introduced by the Directive 34/2013 and especially the effects on small and medium-sized enterprises. It is clear, however, that the most important changes are optional because member states can choose at the implementation time if adopt them or not.

Therefore considered that in Italy the Directive has to be transposed by 20 July 2015, the research highlights some considerations on the proposed new regulations resulting from the implementation of the Directive. In particular, the reflections that the scientific debate is fueling as a result of the participation of the National Council of Certified Accountants to public consultation for the implementation of the Directive. The Italian accountants have a thorough understanding of the issues and difficulties of small and medium-sized enterprises so that their contribution to the transposition and implementation of the new regulations is a fundamental and indispensable.

The contribution of the research is also to disseminate internationally the arguments for and against future legislation in order to feed a comparison with the approaches pursued by other jurisdictions. The research does not take into consideration the new provisions contained in the Directive relating to the consolidated financial statements, the corporate groups, the audit and other specific aspects.

\section{THE NEW DIRECTIVE. SCOPE AND GENERAL PROVISIONS FOR THE PREPARATION OF THE FINANCIAL STATEMENTS}

Pursuant to art. 3 of the new Directive, the beneficiaries of the legislation were grouped based on quantitative criteria to distinguish microenterprises from small businesses from mediumsized businesses and large enterprises while in the case of business groups are separated by small groups, groups of medium-sized and large groups. Table No. 1 shows the characteristics and the quantitative limits in order to identify the different categories of firms.

\section{TABLE 1}

Quantitative criteria to distinguish enterprises

\begin{tabular}{|c|c|c|}
\hline COMPANIES & CHARACTERISTICS & DIRECTIVE 2013/34 / EU \\
\hline $\begin{array}{l}\text { Micro-enterprises: } \\
\text { companies the date of the } \\
\text { balance sheet does not } \\
\text { exceed the limits of at least } \\
\text { two of the following three } \\
\text { criteria }\end{array}$ & $\begin{array}{l}\text { A) Total Balance Sheet: } 350.000 € \\
\text { B) Net revenues from sales and } \\
\text { services: } € 700,000 \\
\text { C) Average number of employees } \\
\text { during the financial year: } 10\end{array}$ & $\begin{array}{l}\text { Article } 36 \text { provides for the } \\
\text { simplification in the preparation of } \\
\text { the balance sheet, income statement } \\
\text { and notes to the financial } \\
\text { statements. Other simplifications } \\
\text { are provided for the preparation of } \\
\text { the management report and the } \\
\text { publication of the financial } \\
\text { statements }\end{array}$ \\
\hline $\begin{array}{l}\text { Small companies: } \\
\text { companies that at the date of } \\
\text { the balance sheet does not } \\
\text { exceed the limits of at least } \\
\text { two of the following three } \\
\text { criteria }\end{array}$ & $\begin{array}{l}\text { A)Total Balance Sheet: } 4.000 .000 € \\
\text { B) Net revenues from sales and } \\
\text { services: } 8.000 .000 € \\
\text { C) Average number of employees } \\
\text { during the year: } 50\end{array}$ & $\begin{array}{l}\text { According to Article 14, Member } \\
\text { States may authorize small } \\
\text { companies to draw up a balance } \\
\text { sheet and an income statement in } \\
\text { abbreviated form. Other } \\
\text { simplifications are provided for in } \\
\text { Article } 31 \text { for the publication of the } \\
\text { financial statements. }\end{array}$ \\
\hline
\end{tabular}




\begin{tabular}{|c|c|c|}
\hline $\begin{array}{l}\text { Medium-sized companies: } \\
\text { companies that at the date of } \\
\text { balance sheet does not } \\
\text { exceed the limits of at least } \\
\text { two of the following three } \\
\text { criteria }\end{array}$ & $\begin{array}{l}\text { A)Balance Sheet Total: } 20,000,000 \\
\text { euro } \\
\text { B) Net revenues from sales and } \\
\text { services: } 40.000 .000 \text { EUR } \\
\text { C) Average number of employees } \\
\text { during the financial year: } 250\end{array}$ & $\begin{array}{l}\text { According to Article 14, Member } \\
\text { States may authorize them to } \\
\text { prepare an income statement in } \\
\text { abbreviated form. Must provide } \\
\text { additional information in the Notes } \\
\text { in accordance with Article } 17\end{array}$ \\
\hline $\begin{array}{l}\text { Large companies companies } \\
\text { that at the date of balance } \\
\text { sheet exceed the limits of at } \\
\text { least two of the following } \\
\text { three criteria }\end{array}$ & $\begin{array}{l}\text { A)Balance Sheet Total: } 20,000,000 \\
\text { euro } \\
\text { B) Net revenues from sales and } \\
\text { services: } 40.000 .000 \text { EUR } \\
\text { C) Average number of employees } \\
\text { during the financial year: } 250\end{array}$ & $\begin{array}{l}\text { These must provide appropriate } \\
\text { additional information in the Notes } \\
\text { in accordance with the provisions } \\
\text { of articles } 17 \text { and } 18\end{array}$ \\
\hline Public interest entities & $\begin{array}{l}\text { These are always considered big } \\
\text { business regardless of the net } \\
\text { revenues from sales and services, the } \\
\text { total assets on the balance sheet and } \\
\text { the average number of employees } \\
\text { during the year. }\end{array}$ & $\begin{array}{l}\text { They must provide additional } \\
\text { information in the Notes in } \\
\text { accordance with the provisions of } \\
\text { articles } 17 \text { and } 18\end{array}$ \\
\hline
\end{tabular}

As for the recipients of the Directive are excluded from the non-profit companies or businesses regulated by other sector-specific rules of their membership. Among the recipients for Italy all companies (Spa, Sapa, Ltd.) and partnerships (SNC and SAS).

The general principles for the preparation of the financial statements Art. No. 4 and No. 6 . These reconfirm what the previous IV Directive already holds: the postulates of level 1 (art. 4) respectively of the "clarity" of the "veracity" and "honesty". To these are added the principles of the second level (art. 6) that the new directive are described in more organic synthesis according to the scheme described in Table No. 2.

\section{TABLE 2}

The postulates of the financial statements

\begin{tabular}{|c|c|c|}
\hline & DIR. $n^{\circ} 78 / 660 / C E E$ & DIR. 2013/34/UE \\
\hline PRUDENCE & $\begin{array}{l}\text { It requires the recognition of the } \\
\text { profit only if they are made and } \\
\text { all losses, even if they are } \\
\text { alleged, in order to guarantee an } \\
\text { income actually produced }\end{array}$ & $\begin{array}{l}\text { New directive emphasized the } \\
\text { concept of product revenue }\end{array}$ \\
\hline GOING CONCERN & $\begin{array}{l}\text { The assessing must be made } \\
\text { according to a going concern } \\
\text { approach and not to break up in } \\
\text { order to attribute a value to the } \\
\text { assets of the company in relation } \\
\text { to their residual value. }\end{array}$ & $\begin{array}{l}\text { New directive emphasizes that } \\
\text { establishing the opening balance } \\
\text { sheet of a financial year must } \\
\text { correspond perfectly to the } \\
\text { closing balance sheet of the } \\
\text { previous year. }\end{array}$ \\
\hline COMPETENCY & $\begin{array}{l}\text { Indicates that the costs and } \\
\text { revenues should be recognized } \\
\text { only to the portion of the actual } \\
\text { economic competence regardless } \\
\text { of their Actual monetary event. }\end{array}$ & \\
\hline $\begin{array}{l}\text { SEPARATE EVALUATION OF } \\
\text { THE } \\
\text { HETEROGENEOUS }\end{array}$ & $\begin{array}{l}\text { Heterogeneous items included in } \\
\text { the individual items must be } \\
\text { valued separately }\end{array}$ & \\
\hline $\begin{array}{l}\text { CONSISTENCY EVALUATION } \\
\text { CRITERIA }\end{array}$ & $\begin{array}{l}\text { Highlights the use of the same } \\
\text { evaluation criteria in order to } \\
\text { ensure the comparability of the } \\
\text { transactions }\end{array}$ & $\begin{array}{l}\text { Emphasizes the 'obligation to } \\
\text { communicate and justify the } \\
\text { changes to the evaluation criteria } \\
\text { in order to avoid misleading the } \\
\text { accounting information. }\end{array}$ \\
\hline RELEVANCE & & Introduced by Directive 34/2013 \\
\hline
\end{tabular}




\begin{tabular}{|l|l|l|}
\hline & $\begin{array}{l}\text { in order to emphasize the need to } \\
\text { detect and represent the values of } \\
\text { the financial statements in } \\
\text { accordance with the "substance" } \\
\text { of transactions. }\end{array}$ \\
\hline
\end{tabular}

It is also established that if the application of a provision of the Directive was incompatible with the principles set out above, it must be set aside and must be indicated in the notes that fact and the reasons therefor.

Other provisions relating to the financial statements are contained in art. No. 9 in which it is stated:

1) The principle of non-changeability from one year to the next of the property to the Balance Sheet and Income Statement to comply with the comparability of the financial statements in future periods (formal continuity principle);

2) The principle of the rigidity of the structure of the financial statements for the year. It is possible to modify the structure, nomenclature and terminology of items only when the particular nature of the enterprise requires it; member states may permit or require the grouping of items preceded by Arabic numbers if a significant amount or such combination makes for greater clarity, but in the Notes must be submitted separately. States is also granted the ability to insert further subdivisions to the voices of the financial statements preceded by roman numerals, to add to the total, partial and additional items.

\section{THE MEASUREMENT OF THE FINANCIAL STATEMENTS ITEMS}

The Directive states that the items of the financial statements should be evaluated primarily based on the purchase price or the cost of production (art. 6, letter i). Special attention is devoted to fixed assets (art. 7) and financial instruments (Article 8) for which there are exceptions to the general principles.

As for the fixed assets, the legislature has held that states may legislate in favor of the companies offering them the opportunity to proceed to the revaluation of fixed assets in order to make "faithful" to the reality the framework of the financial statements.

Therefore, unlike the previous legislation no longer provided for the "replacement value" and "appreciation value" as alternatives to the "purchase price" and the "cost of production" but it is held only the "revalued amount."

With reference to financial instruments, including also "derivatives", the new Directive provides that Member States may authorize assessments to the "net value".

TABLE 3

Principles of valuation of assets and financial instruments

\begin{tabular}{|l|l|l|}
\hline & DIR. ${ }^{\circ}$ 78/660/CEE & DIRET. 2013/34/UE \\
\hline ASSETS & $\begin{array}{l}\text { Replacement Value } \\
\text { Revaluation }\end{array}$ & Method of restating (Article 7) \\
\hline $\begin{array}{l}\text { FINANCIAL } \\
\text { INSTRUMENTS }\end{array}$ & Market value & Net Value \\
\hline
\end{tabular}

With reference to the application of the "restating method", the Directive provides that the amount of the difference between the valuation at purchase price or production cost and the assessment carried out by the method of recalculation be registered in the heading of "revaluation reserve within shareholders' equity". The revaluation reserve may not be reduced except in the case where the amounts charged to this reserve are no longer necessary for the application of the method of restatement. 
Member States may lay down rules governing the use of the revaluation reserve while respecting the provision that no part of the reserve may be distributed, directly or indirectly, unless it corresponds to a realized gain. The reserve may be wholly or partly converted into equity at any time.

The Italian legislation does not provide for a similar method at the time, but there are specific laws that allow the revaluation of certain types of assets (buildings and land) to take into account the real current value. The net value method is an alternative method that can be applied to different types of assets. It is governed by. 9 according to which Member States authorize or prescribe, for all companies or any classes of companies, the assessment of the net value of financial instruments, including derivative financial instruments, and assets other than financial instruments (Roscini Vitali, 2013). These factors include current assets and non-fixed assets, which are measured according to the method of restating.

The valuation based on the net value applies only to the following liabilities:

1) liabilities held as part of the trading portfolio

2) derivative financial instruments

It does not apply to:

1) Non-derivative financial instruments held to maturity;

2) loans and receivables originated by the enterprise and not held for trading purposes,

3) investments in subsidiaries, associates and interests in joint ventures, equity instruments issued by the company, and contracts that provide for contingent consideration as part of a business combination, as well as other financial instruments whose special characteristics that, according to what is generally accepted, should be accounted for differently from other financial instruments.

The changes in value are included in the income statement, except in the cases listed below, in which these changes are recognized directly in a reserve of net value of equity:

the instrument accounted for is a hedging instrument, as part of a hedging transaction that allows you to not enroll in the income statement for all or part of the change in value;

the change in value relates to an exchange difference arising on a monetary item that forms part of an investment's net investment in a foreign entity.

The Member States may permit or require that the change in value of a financial asset available for sale, other than a derivative financial instrument is recognized directly in reserve of net valuet. This is adjusted when amounts shown therein are no longer necessary for the application of the method of the net value.

Member States may permit or require all companies or for certain types of businesses, that when an asset other than a financial instrument is valued at net book value, a change in value is recognized in the Income Statement.

The definition of net value depends on the type of activity:

1) market value for financial instruments for which it is possible to easily locate a reliable market;

2) market value that can be derived from components or a similar instrument, if the market value is not readily identifiable for an instrument but can be identified for its components or for a similar instrument;

3) market value resulting from models and valuation techniques generally accepted, as long as these models and valuation techniques to ensure a reasonable approximation of the market value.

The advantages of the net method are to provide the latest data on the value of the assets, thus providing more accurate information, and the objectivity of the same, as determined by reference to the market value (Quagli, 2006).

The limitations are: 
1) the lack of accuracy when there are no markets considered that is based on values derived from models and measurement techniques for the estimation;

2) the great variability of the value, linked to the difficulty in applying the method of the net value than the purchase price or the cost;

3) greater difficulty in applying the method of the net value than the purchase price or the cost.

This method is therefore the main effect of tying in part the trend of the performance to the market, which still constitutes a risk factor because of its potential volatility (Marcello R., Lucido N.,2013)..

\section{THE STRUCTURE OF FINANCIAL STATEMENT}

In order to ensure compliance with the postulates of the balance sheet and thus facilitate the internal and external stakeholders to understand and compare the analysis of balance sheets, profit and financial enterprises both domestic and European, the new EU directive reiterates the same way as the one currently in force, that the structure of the balance sheet and income statement cannot be modified except in exceptional circumstances in line with these principles of "truthfulness", "fairness" and "clarity".

Article 4 paragraph 1) indicates mandatory documents and certifies that the financial statements shall include at least the Balance Sheet, Income Statement and the Explanatory Notes. In the previous version, the Income Statement was called "Profit and Loss" and the Notes document was referred to as "attachments". In addition to these documents, Member States may require additional prospectuses depth (art. 4, par. 1, paragraph 2) as well as additional information (art. 4, par. 5 and 6) for medium-sized and large enterprises. Even in this circumstance is reiterated the need to simplify the administrative burden for small businesses. With regard to the format of the schemes, Directive prescribes the Balance Sheet Annexes $\mathrm{III}^{\circ}$ and $\mathrm{IV}^{\circ}$ and those of Income Statement in Annexes $\mathrm{V}^{\circ}$ and $\mathrm{VI}^{\circ}$ and the contents of the Notes in Chapter 4.

With reference to the balance sheet, there are two statements:

1) a horizontal structure or opposing sections as required by the current article. 2424 of the Civil Code. The scheme essentially corresponds to that in force providing some differences in classification and repositioning of the voices of deleting accounts.

2) a vertical structure or scalar of the accounts of assets and liabilities

The article 10 provides for the possibility for Member States to authorize a structure of the balance sheet based on the difference between current assets and current liabilities and those extra current.

Undoubtedly, the introduction into the Italian classification of items according to the "managerial relevance" and the possibility of a vertical structure represent a real innovation compared to what it can do today

It is clear that the discretion allowed to Member States could undermine some of the objectives that the legislation is aimed first the comparability of financial statements between companies located in the same state as well as between enterprises in different states.

With regard to the income statement (art. 13, par. 1) the structures are set out in Annexes $\mathrm{V}^{\circ}$ and $\mathrm{VI}^{\circ}$. In the first accounts of income are classified by type according to the scheme that follows the one in force and held art. 2425 Civil Code, while showing some differences. In particular, the updated version has been simplified with the elimination of some items: macros items marked by letters have been eliminated leaving only the items marked by arabic numerals. The new directive also provides for the elimination of macro item E) extraordinary income and expense. 
This rule is a modification not only formal but also substantial. The distinction between ordinary and extraordinary revenues and expenses must instead be compulsorily mentioned in the Notes pursuant to art. 16, paragraph 1, letter. f. Consequently, the income statement, which already makes it impossible to know in a rigorous way the operating profit in the year, loses further information value. Do not highlight in the income statement as an extraordinary item of income, if these components were to be significant, could affect the understanding of the situation of the company, especially to outsiders who do not have other information.

Annex VI regulates the structure of the income statement according to the functional approach ("as a function of spending") according to which the classification of items is based on the destination of the goods or services rather than by the nature of such goods.

The new directive does not provide for schemes in the Income Statement as opposed to sections but admits the possibility pursuant to art. 13, c. 2 that a Member State may require or permit to replace the profit and loss statement with an account of the performance, provided the information.

With regard to the content of the notes, the new directive requires disclosures about the accounting policies adopted (art. 16, par.1, letter a) to evaluate accounts of the financial statement and not the reference to the evaluation method.

Another innovation concerns the content of the note reformulated according to the size of company. The content especially for small businesses is significantly reduced compared to what is in force in accordance with art. 2427 Civil Code. Instead the art. 18 clarify the additional content that is to be met only by large enterprises and by public interest entities.

Among the other innovations, the possibility of drawing up the financial statements in abbreviated form (art. No. 149) not only to small and medium-sized enterprises but also micro enterprises.

\section{CONCLUDING COMMENTS}

The new Directive confirms the existing laws on the subject of financial statements through introducing a number of changes most of which show a more formal than substantial aspects. The main news regarding the financial statements is the introduction of alternative schemes of the Income Statement and Balance Sheet are based on very different logic than the current one. With regard to the aspect of the evaluation of balance sheet items, it's introduced alternative valuation of fixed assets, based on the amounts restated and also the alternative valuation based on the net amount which constitute only part of the news because some of the predictions are already present in the existing legislation.

The legislation makes a rationalization of the financial statements adapting the features to the size of the quantitative parameters through well defined. However, the most important changes are optional in the sense that Member States can choose when transposing whether or not to adopt them. In the Italian case will be unlikely to introduce radical innovations in the financial statements, because they are too alien to the current framework. The optional nature of many options may be limits to the goal that puts the Directive. In fact, the considerable discretion left to the Member States may prevent the achievement of uniformity and consequently the comparison between the financial statements of companies of different nationalities.

For these considerations and because the Directive has not yet been transposed in Italy, it becomes difficult to express an opinion on the effects this could have on its effectiveness in achieving the objectives for which it was conceived.

Undoubtedly there are many thoughts about partly because the critical aspects contained in the new Directive are many for whom the debate between professionals and associations is somewhat turned on. In the first place, the general approach of a modular basis so that the 
requirements on transparency of financial statements and governance should be proportional to the size and importance of the business even if viewed positively highlights some limitations.

A simplification of administrative and accounting controls for small businesses in order to reduce the administrative burden is likely to not highlight the critical issues typical of smaller companies thus creating damage to the entire economic system. Even the approach to the provisions contained in the international accounting standards IAS / IFRS does not lend itself to SMEs. The information needs of SMEs are different because they aim to meet the knowledge of other categories of stakeholders such as banks, shareholders, business partners, exchequer.

For this reason, some accounting professionals believe that the evaluation principle based on the historical cost is still a valid measurement technique of the events, facts and business operations. This does not mean that historical cost is the only method to be taken into consideration but the first to be used and where it is not suitable to represent properly the economic and financial situation of enterprises will be useful to identify alternative assessment with reference to the parameters dimensional. In addition, the European Union has revised the dimensional parameters in recent years several times in order to widen the scope of businesses that can provide accounting and regulatory simplification. A further increase of the thresholds considered also the continuing crisis period and the simultaneous decrease in the carrying value might not accurately represent the reality of SMEs. Excessive unpacking of the corporate reality envisaged by the directive is counterproductive because providing multiple categories likely to produce frequent changes in accounting models, creating difficulties for operators forced to change the system setting data and significant complexity to the tax authorities have to define a mechanism extra accounting can eliminate the differences arising from the simplifications determine whether these effects on the measurement of the items. For these reasons, it might be more appropriate to provide only two categories of reality, namely small businesses and non-small businesses with the added then the category of public interest entities.

\section{REFERENCES}

Communication COM (2010) 543, European Parliament Commission: The European Economic and Social Committee and the Committee of the Regions "Smart Regulation in the European Union".

Directive 2013/34 / EU, European Parliament, June 26, 2013

Marcello R. \& Lucido N.(2013), La Direttiva n. 34/2013 del Parlamento Europeo e del Consiglio del 26 giugno 2013 in materia di bilanci. Il Fisco 37/2013 fascicolo 1, Gruppo Wolters Kluwer, Roma. pp. 5696-5704.

Quagli A., (2006), Il Bilancio d'esercizio e i principi contabili, Giappichelli, Torino. Roscini Vitali F. (2013), Nuovi bilanci dal 2016. Guida alla contabilità. Il sole 24 Ore. Milano. 